\title{
Ceruloplasmin Measurement
}

National Cancer Institute

\section{Source}

National Cancer Institute. Ceruloplasmin Measurement. NCI Thesaurus. Code C100432.

The determination of the amount of ceruloplasmin present in a sample. 